Pivot is published through Open Journal Systems (OJS) at York University

Abstract: This essay constructs a postcolonial theoretical framework to investigate a scene in Ernest Hemingway's 1926 novel, The Sun Also Rises. The scene suggests that an African-American character-a musician performing the popular jazz song, "Aggravatin' Papa"-may share a sexual history with the novel's white female protagonist. The text strategically silences the black character's voice at several moments in the dialogue. By exhuming the musician's lyrics and showcasing the silenced voice in this intertextual relationship, I argue that the marginalized minority voice is, in fact, central to Hemingway's modernist experimentation. In the very process of its appropriation and silencing in the novel, the black presence bursts forth from its liminal discursive space and intervenes in the narrative's construction of difference.

\title{
"Aggravatin' Papa": Race, Omission, and Discursive Liminality in Ernest Hemingway's The Sun Also Rises
}

○

Walter Bosse

There is no

binary division to be made between what one says and what one does not say; we must try to determine the different ways of not saying such things, how those who can and those who cannot speak of them are distributed, which type of discourse is authorized, or which form of discretion is required in either case. There is not one but many silences, and they are an integral part of the strategies that underlie and permeate discourses. ${ }^{1}$

Throughout his career, Ernest Hemingway continually reflected upon the aesthetics of his prose fiction. In his treatise on bullfighting, Death in the Afternoon (1932), Hemingway first named his now famous and much-celebrated "iceberg theory" of writing:

${ }^{1}$ Michel Foucault, The History of Sexuality, Volume I: An Introduction, 27. 
If a writer of prose knows enough about what he is writing about he may omit things that he knows and the reader, if the writer is writing truly enough, will have a feeling of those things as strongly as though the writer had stated them. The dignity of movement of an ice-berg [sic] is due to only one-eighth of it being above water. A writer who omits things because he does not know them only makes hollow places in his writing. (192)

Hemingway's metaphor has profoundly influenced generations of writers. Discussions of omission-as-technique in the literary arts poorly represent the topic if they neglect to address the significance of Hemingway's precedent. However, far too often, those critics who do explore the author's process of omission only succeed in valorizing its aesthetic effects and touting its innovation. While this type of criticism purports to substantiate the iceberg theory as a subject that still merits our attention, it also tends to overlook the most fascinating and problematic component of the technique: the actual content that gets silenced.

In what follows, I focus on a scene in Hemingway's 1926 novel, The Sun Also Rises, which involves several textual omissions within the characters' dialogue. This scene occurs at the end of Book One, when the novel's two primary protagonists-Jake Barnes and Lady Brett Ashley-patronize Zelli's jazz club in the Montmartre district of Paris. Historically, this district drew and supported the greatest number of African-American expatriates during the interwar years, many of whom were jazz artists. There, Jake and Brett drink, dance, and 
interact with an unnamed black drummer who is in the middle of a performance. The nuances of their exchange suggest that Brett may have had a sexual encounter with the drummer, and it is his voice that the text selectively mutes. Interestingly, these particular omissions remain manifest to the reader in the published version. In other words, the narrative suppresses much of the musician's speech by depicting his utterances in ellipses, as apparent blanks within the dialogue: for example, "'. . . . . .' the drummer chanted" (Sun 70). Thanks to the scholarship of James Hinkle and Frederic Svoboda, however, we know the content behind the ellipses, because the drummer sings an actual jazz song at the same time that he addresses Brett. ${ }^{2}$ At one point, he vocalizes the lyric, "you can't two time" (Sun 70), a sexually suggestive phrase that constitutes part of the chorus in the popular jazz tune "Aggravatin' Papa (Don't You Try To Two-Time Me)," composed by Roy Turk and J. Russel Robinson in the early 1920s. As my analysis will show, Hemingway both appropriates and suppresses a song about race and sexuality at a moment when the novel's white female protagonist is implicated in an interracial sexual affair.

By exhuming the complete lyrics of "Aggravatin' Papa" and setting them against Hemingway's narrative in my analysis, I illustrate the

${ }^{2}$ Svoboda identifies the title of the song in his scholarly note, "Who Was That Black Man?: A Note on Eugene Bullard and The Sun Also Rises"; he also claims that the unnamed drummer is Eugene Bullard, "a personage of some distinction" in American expatriate circles (106). Like many critics, he reads the novel as a roman à clef. Despite the popularity of that approach to the novel, no one has fully explored the intertextual potential of the lyrics. 
complex racial and sexual politics that inform his process of omission. To this end, my method partially follows from Edward Said's call for "contrapuntal reading" in the context of postcolonial theory, which "must take account of both processes, that of imperialism and that of resistance to it, which can be done by extending our reading of the texts to include what was once forcibly excluded" (66-67). By giving voice to the muted element within Hemingway's canonical text, we can make advances toward a more inclusive and insightful vision of The Sun Also Rises's compositional strategies and ideological underpinnings. Theorizing about the silences that constitute Hemingway's texts allows us to investigate the complex politics of representation contained in the iceberg theory. By showcasing the silenced voice in this intertextual relationship, I hope to illustrate the centrality-indeed, the constitutive force-of the minority voice within Hemingway's modernist experimentation. In the very process of its appropriation and silencing in The Sun Also Rises, the black presence bursts forth from its liminal discursive space and intervenes in the narrative's construction of difference. An internally colonized voice, the drummer's silence can be seen to exert a realized power that Homi Bhabha sees as "both politically effective and psychically affective because the discursive liminality through which it is signified may provide greater scope for strategic maneuvre and negotiation" (208, italics in the original). This complex textual situation therefore stages a theory of discursive power decades ahead of poststructuralist arguments about subjectivity. 


\section{I.}

In resurrecting the full text of "Aggravatin' Papa," I give the silenced voice rhetorical priority. However, before doing so, it is necessary for me to provide narrative context and look at the song's appearance and suppression in the novel. The scene in Zelli's brings Hemingway's formal strategies into extreme focus; furthermore, it evidences an apparent ideological crisis at the root of the novel's response to race and to the possibility of an interracial sexual encounter. The Zelli's episode reveals an intimate link between race and the novel's stylistic innovation. Reading this section in light of the omitted lyrics, I not only illuminate the intertextual relationship between Hemingway's craft and African-American jazz, but also I attempt to open up specific power relations constructed by the literary-lyrical discourses of nation, sex, and race.

Upon entering Zelli's club, Jake's narration suggests the immediate and literal impact of the scene: "[t]he music hit you as you went in" (69). The diction in this sentence suggests the overwhelming quality of the band's sound, but-more importantly-serves as a jarring narrative signal. The experience of simply entering the club indicates a profound shift; the enveloping sounds of jazz presage the impact of the chapter's impending interactions. The heightened level of anxiety in Jake's narration corroborates the active and powerful influence of the music and the musicians. During the course of Brett and Jake's initial dance-there are several that occur in this scene-Brett and the drummer exchange what appear to be quick cordialities. Hemingway's 
minimalist prose nearly conceals the crux of the meeting: namely, that Brett and the drummer may well share a sexual history. Jake observes that the "nigger drummer waved at Brett" (69). In the middle of their dance, they end up directly in front of the band, where the drummer asks her, "Hahre you?" (69). Jake's non-dialogue narration then supplies the racist remark that "[h]e was all teeth and lips," a rhetorical response that intuits the sexual transgression, and defends against it violently by relying on racial epithets and fragmenting the drummer bodily. Brett then tells Jake that "[the drummer] is a great friend of mine... Damn good drummer" (69). As historian Tyler Stovall maintains, "[b]ecause no aspect of American bigotry had harsher consequences than did the prohibition against miscegenation, one could easily view the ability to engage in interracial sex as the ultimate liberation from racism" ("Gender" 24). The drummer's relationship with Brett does stage a specific intimacy, though the relationship in and of itself does not constitute the exact type of "liberation" that Stovall describes. Their sexual encounter can, however, be seen as a kind of threat to white American patriarchy: it excludes Jake, who infers it and recoils against it in the narrative.

In another study of interracial networks in the City of Light, Stovall claims that "[i]n 1920s Paris, white Americans observed blacks with interest and sympathy but ultimately... as outsiders" (80). By allowing Jake and Brett to become an object of observation for the black drummer, the text complicates the patronizing white gaze recorded by Stovall. The drummer briefly moves out of his objectified role. Though 
Jake's narration relies on synecdoche to tear him to pieces-"all teeth and lips"-there is apparently enough left of the drummer for him to look back, smile, and engage Brett. Jake's disgusted reaction at the possibility of Brett's transgression functions as the baseline of American moral and racial propriety. In part, the anxiety and anger he expresses in this passage evinces a desire to uphold conventional, segregated attitudes about race and sex. Increasingly, as the chapter nears its conclusion, the narrative gives greater attention to Jake's internalization of the scene. Though external details still permeate the text, the direct references to Jake's psychological stress convey an expressionist aesthetic:

"Come on. Let's dance," Brett said.

We danced. It was crowded and close.

"Oh, darling," Brett said, "I'm so miserable."

I had that feeling of going through something that has all happened before. "You were happy a minute ago."

The drummer shouted: "You can't two time-" (70)

This slightly shifted focus to Jake's inner turmoil-that is, his anxieties about miscegenation-sets up the potential for a direct commentary on racial ideology. However, the text ultimately retreats from such a direct confrontation and instead turns to formal omissions, silencing the drummer's voice. When reading this passage, it is imperative to consider the ambience: "Aggravatin' Papa" permeates the space, and 
Jake is made to dance to its rhythms. The passage performs these tensions. The following proceeds directly from the drummer's shouted lyric, and the dialogue begins with Brett:

"It's all gone."

"What's the matter?"

"I don't know. I just feel terribly."

". . . . ." the drummer chanted. Then turned to his sticks.

"Want to go?"

I had the feeling as in a nightmare of it all being something repeated, something I had been through and that now I must go through again.

"....." the drummer sang softly.

"Let's go," said Brett. "You don't mind."

". . . . ." the drummer shouted and grinned at Brett. (70-71)

The companion piece to the initial dance, this passage follows the general pattern set forth in Brett and Jake's first movement through the club. Where the first interaction with the drummer suggests Brett's intimacy with him-by way of Jake's reaction and her subtle recognition of their "great" friendship-this second dance makes it much more explicit in the line "You can't two time." This common sexual innuendo would be well known to any reader; the drummer's 
oblique, recurrent presence within the dialogue strengthens the sexual implications of two-timing, and his final appearance shows him smiling at Brett. The exchange exhibits what J. Gerald Kennedy identifies as Hemingway's "preoccupation with innuendo, body language, glances, clothing-with what might be called the semiotics of desire" (87). The nuances of the exchange are complex, as the text performs a kind of stylistic gymnastics in an attempt to defuse the volatility of the racial and sexual transgression.

Indeed, Hemingway here employs more of a stylistic mélange than he does when describing the first dance; he retains some of the impressionism in such sentences as "It was crowded and close," and amplifies the teeming, congested, and nervy atmosphere by splicing the drummer's vocals into the Jake-Brett dialogue. The suddenness of Brett's mood swing implies that the content of these vocals-mostly omitted in the text-is at the root of the narrative's inward turn. The text turns partially expressionistic, both in Brett's admission that she is "so miserable" and, perhaps most prominently, in Jake's internal narration: "I had that feeling of going through something that has all happened before... I had the feeling as in a nightmare of it all being something repeated, something I had been through and that now I must go through again" (71). The drummer-in the background, and mostly denied a voice-still permeates every nuance of the dialogue between Brett and Jake. In this way, the drummer's silenced voice still manages to play an active role within the narrative. Despite the suppression of his voice in the text, the drummer exerts a palpable 
force. Thus, his conspicuously silenced voice dramatically impacts the novel's representational strategies, suggesting that silence itself "is less the absolute limit of discourse, the other side from which it is separated by a strict boundary, than an element that functions alongside the things said, with them and in relation to them within over-all strategies" (Foucault 27).

On one hand, the scene in Zelli's becomes "an emotional and intellectual complex in an instant of time," whereby the writer exerts "concentration, vivid sensory evocation of scene, implication without authorial comment, [and] artistic control" (Nagel 22); on the other hand, Hemingway's ostensible control appears jeopardized by the complete suppression of language evidenced in the drummer's elided speech. Such a move goes far beyond a selective omission of details, and exemplifies, in Marianne DeKoven's words, how the politics of modernist form "inhabits and perhaps describes the space of unresolved contradiction or unsynthesized dialectic" (679). The possibility of interracial sex violates Jake's exported, segregationist value system, and consequently generates the distress that the novel's impressionism, expressionism, and omissions struggle to convey and assuage. The experience of race, then, becomes a flashpoint in the epistemological framework of Hemingway's aesthetics.

Jake's "feeling as in a nightmare of it all being something repeated" (71) potentially suggests his emasculation on the dance floor. It could echo the physical trauma of his war wound, which rendered him 
sexually impotent, and seeing the drummer achieve an intimacy with Brett only serves to exacerbate that loss. This interpretation will be incredibly tempting to readers familiar with the Hemingway Code, in which such values as loyalty, valor, grace-under-pressure, and masculinity figure largely. However, as Comley and Scholes illustrate, "looking for The Code... is an attempt to reduce a complex textual phenomenon to an excessively simple formula" (8). While "decoding" the crisis of Jake's masculinity might satisfy those interested in rehashing and simplifying the writer's ethical imperatives, such a reading nonetheless remains critically limited and blind to the fascinating intertextual complexities introduced by the song. Amy Strong attenuates the racial objectification involved in such criticism, arguing that "[s]cholars have noted the presence of Native Americans, Africans, and African Americans in his work, though few have viewed these characters as anything more than scenery; for most, the racial elements in Hemingway's works have served primarily as a backdrop to more central issues of manhood, courage, and stoicism" (4). So, we must bring this backdrop forward, and resituate that which has been omitted and marginalized in the text and in the criticism.

\section{II.}

Bhabha's discussion of discursive liminality bears special relevance not only to the aesthetic and ideological nuances within "Aggravatin' Papa," but also to the manner in which the song appears in The Sun 
Also Rises. Deployed by Hemingway as a subtext within the novel's Parisian cityscape, the song performs where U.S. regional modernity and expatriate international modernism intersect. Demonstrating "the importance of locality to modernism's world-imaginary" (Herring 3), the regional, racial, and sexual dynamics of the jazz tune profoundly impact Hemingway's international vision and craft. Critics such as J. Gerald Kennedy have done much in the way of explicating "the primacy of place in the [expatriate] writer's conception of self" (11); observing the moment of the song in The Sun Also Rises expands such critical readings, and provides new insights about the primacy of race in modernist conceptions of self, power, and aesthetics.

In view of the muted content from "Aggravatin' Papa," the technical strategy of omission participates within a network of discourses about race, gender, and sexuality. Provided below, the lyrics to "Aggravatin' Papa" elaborate a tale of male promiscuity and infidelity. An unidentified, third-party witness to the song's drama narrates its introduction, also known as the pre-chorus, and the remaining verses come from the perspective of the betrayed woman. I have transcribed the following lyrics directly from the sheet music to "Aggravatin" Papa," published by Waterson, Berlin \& Snyder Company in 1922:

[First Pre-Chorus]

I know a triflin' man,

They call him "Triflin' Sam."

He lives in Birmingham,

'Way down in Alabam'. 
Now the other night,

He had a fight

With a gal named Mandy Brymm,

And she plainly stated she was aggravated,

As she shouted to him: $(3)^{3}$

The pre-chorus serves as a preface, and though it lacks the lyrical personality and rhetorical force of the chorus and coda, this prefatory component is vital to the song's signification because it situates the conflict within a specific geographical milieu. ${ }^{4}$ The preface tells us that the drama takes place "'Way down in Alabam""; depending on one's lyrical interpretation, this line invites two different ways of locating Birmingham, both of which place it at a cultural extreme. Read simply as "way down in Alabama," the line recognizes that a significant distance separates the narrator from the scene she sets up; if we retain the apostrophe and read "'Way" as "away" in dialect, then the song's narrator further accentuates the distance and alterity of Birmingham, which locates it not only at a significant geographical remove, but also imparts to it a sense of isolation and regional closure. In The Nation's Region: Southern Modernism, Segregation,

${ }^{3}$ For the purposes of this study, I limit my analysis to the first pre-chorus, the main chorus, and the first coda. However, the musical score indicates that there are multiple repeats, and-with the exception of the main chorus-the vocals change with each repeat. To view the subsequent verses in the full text of the sheet music, see Roy Turk and J. Russel Robinson, Aggravatin' Papa (Don't You Try to Two-Time Me) (New York: Waterson, Berlin \& Snyder Co., 1922. 3-5).

4 It is important to note that "Aggravatin' Papa" has many precedents in both the jazz and blues traditions. For example, "St. Louis Blues"-written by W.C. Handy in 1914 and most famously performed by Bessie Smith-also articulates a female's anxiety over male abuse and sexual exploitation. 
and U.S. Nationalism, Leigh Ann Duck illustrates how the imaginative space of the American South often served as a regional counterpoint to the "progress" of the North; as a spatial metaphor, the South functioned as a barometer that allowed Northerners to index their own advanced temporality. Viewed as historically "backward," the South assumed certain metaphoric properties and became a way for "enlightened" writers to symbolize the "modernity" of Northern cities (Duck 3).

In Turk and Robinson's song, the South serves as a regional signifier informing listeners that Mandy's sexual desires, frustrations, and hostility take place in "another temporality," in a realm out of sync with the linear movement of nation-time (Bhabha 205). Thus, the pre-chorus can be seen as an attempt to displace the threat of female resistance, to remove and defuse her anti-patriarchal maneuvers-her "distracting presence"-to a marginalized location. Controlling the threat in this internal Third World allows for the image of national synchrony and white hegemony to remain intact. The song clearly stages the conflict in a region marked by both ethnic and chronological distance, far removed from an imagined, invisible, and normative "center." This rhetorical removal "has persistently shaped traditional representations of the other" (Robison 63), and the song's introductory verse enhances that effect.

The chorus suggests that the song is primarily about female resistance to patriarchy, to male hegemony. Both the chorus and the coda represent Mandy's direct statements to Triflin' Sam: 
[Chorus]

Aggravatin' papa, don't you try to two-time me,

I said, 'don't two-time me!'

Aggravatin' papa, treat me kind or let me be,

I mean, 'just let me be.'

Listen while I get you told

Stop messin' 'round, [with my] sweet jelly roll,

If you step out with a high brown baby,

I'll smack you down and I don't mean 'maybe.'

Aggravatin' Papa, I'll do anything you say

Yes, anything you say.

But when you go struttin', do your struttin' 'round my way. (Turk and Robinson 4-5)

The action is figured as a domestic dispute between a black woman and her unfaithful lover. Mostly spoken from Mandy Brymm's perspective, the lyrics convey a sense of a violent opposition to Triflin' Sam's two-timing ways. The lyrics also portray a racist caricature of black masculinity, in that Triflin' Sam can be seen to represent the cultural stereotype of the hypersexual and amoral African-American man. In this way, Turk and Robinson's song "brings into being that very situation to which it is also, at one and the same time, a reaction" (Jameson 82 ). The song attempts to resolve the dual "threats" of both black male sexuality and female opposition by textualizing them and differentiating them as roles acted out in a black drama circumscribed in the American South. 
Clearly, the voice of Mandy Brymm stands in violent opposition to her male love interest and his licentious behavior. Writing for black performers, Turk and Robinson-two white men-were involved in an incredibly complex rhetoric of racial representation. Subsequently, both Mandy Brymm and Triflin' Sam can be seen as constructs of a white racial imaginary, and specific elements of the song then resemble certain racist stereotypes. The overtones of domestic violence that permeate the song convey an amoral home space, a fictionalized barbaric counterpoint to the familial values of a white middle class. Mandy's repeated line, "Stop messin' round with my jellyroll," casts her as a fetish object, as an overly sexualized black woman whose subjectivity gets elided by a one-dimensional stereotype defining her by her sexuality. Triflin' Sam, too, constitutes a social "type" by virtue of his sexualized nature, and so perpetuates a racist vision of black masculinity. Such textual evidence, read against Turk and Robinson's positions as white composers of jazz, demonstrates critic Michael North's contention that "Anglo-American modernism is dangerous in its very relevance" (11) to forms of black cultural production.

The performance of such stereotypes by African-American musicians does present a major problem, but the compositional history of the song does not necessarily preclude its efficacy as a black performative text. In his study of jazz and social theory, Burton W. Peretti explains how the music performs artistically the oppositional register later articulated by postcolonial theorists: 
African-American creators of jazz, descended from victims of colonization, displacement, and enslavement, belonged themselves to generations which continued to suffer from injustice and to seek healing... by mediating between alienation and tradition, [jazz] has worked to strengthen the bond between artistic modernism and folk culture which has energized much postcolonial writing. (90-91)

As a jazz production, "Aggravatin' Papa" signifies both at the level of written text, and as a performative gesture; in the latter case, the vocal enunciations of a black female singer enact the resistance and potentially disrupt the patriarchy inscribed in the song's composition. ${ }^{5}$

Mandy communicates her resentment toward the patriarchal arrangement by performing a subjectivity outside the constraints of societally prescribed "femininity." In the first coda, she wields a gun and is apparently ready to use it:

[First Coda]

So papa, just treat me pretty, be nice and sweet,

'Cause I possess a forty four that don't repeat,

Aggravatin' papa, don't you try to two-time me! (Turk and Robinson 5)

${ }^{5}$ For example, in 1923, the jazz singer Alberta Hunter recorded a performance of "Aggravatin' Papa" in which she improvised on the coda in such a way as to enhance Mandy's threat of violence against Sam: "Got one hand on my razor, one arm around my gun, / If I catch you foolin' round, I'll tear your doghouse down, / So, Aggravatin' Papa, don't you try to two-time me!" (Hunter). 
Her performance beyond the boundaries of expected gender roles has an analogue in Brett, who wears her hair short, dons men's hats, remains promiscuous throughout the novel, and "is dangerously close to overturning the categories upon which male and female identity, and patriarchal power, depend" (Moddelmog 247). In short, the lyrics assume profoundly new semantic properties when they register at the level of performance, and this is communicated by their cryptic presence in Hemingway's text.

Considering these performative challenges to patriarchal power, what are we to make of the perpetually silent object of Mandy Brymm's anger, the titular figure of the song? Identified both as an "Aggravatin' Papa" and as "Triflin' Sam," it is illustrative to read this shadowy presence as representative of a repressive national patriarchy. Indeed, combining "Papa" with "Sam" conjures up a familiar authority figure (one known more commonly by the title "Uncle," and usually complete with patriotic regalia). Considering this in light of the regional implications of the first verse, it then becomes possible to read Mandy Brymm - "Way down in Alabam"-as articulating an oppositional narrative from the margins against what Bhabha terms the "pedagogical," hegemonic narrative of the nation (222). This interpretation of the song ascertains a real potentiality within the margins of social experience, here located in the black cultural milieu of Birmingham, and so challenges the discursive containment exercised by the rhetorical distance of the song's prechorus. In view of the region's longer history, marked by centuries of 
slavery and decades of post-bellum policies that allowed for regional neglect, racial inequality, and white terror, the song's political consciousness assumes even greater urgency as it challenges the conditions of the dominant social order.

So, the lyrics of "Aggravatin' Papa" can be seen to contain evident traces of this long history. The song approaches American racism through the dramatic framework of domestic turmoil, which it casts in a decidedly Southern geography, and channels through one of the most politically dispossessed subjects of the time-a black woman. Chela Sandoval's theoretical application of "oppositional consciousness" clarifies the song's sociopolitical registers; though she discusses opposition in the historical context of critical theory, her claims are directly applicable to this textual situation. For Sandoval, third-world minority discourses constitute "internally colonized communities" (75) that exist within the context of the so-called First World of the U.S. As a consequence, such a scenario creates forms of consciousness keyed into the machinations of the dominant social order, but which work against those ideologies to change them.

At this level, Sandoval terms such an operation as one of "differential consciousness [which] is the expression of the new subject position... [and which] permits functioning within yet beyond the demands of dominant ideology" (77, emphases added). As an expression of a differential consciousness, "Aggravatin' Papa" strategically negotiates the geopolitical contours of its internal-Third-World milieu. Sandoval's reliance on spatial figures helps to substantiate the political valences 
underpinning the song's regional setting. Furthermore, her recognition that a minority subject can signify "within and yet beyond" the constraints of the dominant ideology allows us to continue to recognize oppositional potential in a song written by two white composers. Indeed, the compositional history of a text and its performative value can be assessed on two entirely different levels; here, the black female vocals operate on "an altogether different register" (Sandoval 77) that gives agency back to Mandy Brymm.

In the song's chorus, Mandy asserts that "If you step out with a high brown baby, / I'll smack you down, and I don't mean 'maybe'" (Turk and Robinson 3). Her anger derives from his infidelity, but is significantly concentrated in the fact that his other love interest is "high brown"-that is, a light-skinned African-American woman. As critics and historians have thoroughly shown, the hierarchical structure of the white/black binary infiltrated the cultural imagination of African-American communities, where a lighter skin tone was often seen as more desirable than a darker one. Thus, by calling out Papa for his preference of a light-skinned girl, she aligns him with the oppressor, and thereby makes of him a suitable substitute.

The song therefore attempts to negotiate the crisis of racial and sexual politics in America, and it does so by deploying an imaginative geography attuned to the ideological discourses of racial, regional, and national identity. Performed by the black singer, it is not merely a reflection of social discontent, but a conscious and active confrontation with totalizing national discourses that perpetuate racist 
ideologies. Thus, the cry "Aggravatin' Papa, don't you try to two-time me!" represents a potentially revolutionary sentiment. Mandy Brymm's voice sounds from the marginal space of an abject South; she cuts across the privileged space of the nation and crafts a performative subjectivity.

With the 1920s directly on the heels of the racial nadir in that region, it is difficult to ignore the political implications of this lyrical space. Black Birmingham appears as a kind of Third-World space within the song, and Mandy Brymm's voice represents a minority discourse speaking within and against the constraints of the First World; that is, her enunciations contend both with the patriarchal forces in the song itself and with the constraints of Hemingway's appropriation of the song into his novel. Gyan Prakash offers a vision of this arrangement similar to that set out by Sandoval: "third world voices... speak within and to discourses familiar to the 'West'.... The Third World, far from being confined to its assigned space, has penetrated the inner sanctum of the 'First World' in the process of being 'Third Worlded'" (qtd. in Bhabha 354). In the process of being written over in The Sun Also Rises, the minority presence emerges within a liminal space from which it "can intervene in the unifying and totalizing myths of national culture" (Bhabha 358), myths that perpetuate fantasies about racial and sexual difference.

To be sure, this rhetorical push-and-pull between containment and resistance plays out within Hemingway's novel. He appropriates the song into the text and suppresses the drummer's voice 
simultaneously. This move produces and then displaces the threat of Brett's interracial experience. Transgressing the color line, Brett's involvement with the drummer represents an implicit challenge to white male hegemony; by textualizing this social contradiction, The Sun Also Rises perpetuates "the illusion that the situation did not exist before it, that there is nothing but a text, that there never was any extra- or con-textual reality before the text itself generated it in the form of mirage" (Jameson 82). However, by virtue of the song's discursively liminal position in the novel, Hemingway's formal attempt to control, resolve, and displace the social contradiction via omission shows his dependence upon the minority voice and upon the imagined peripheral space of the U.S. South. Bringing the social implications of Turk and Robinson's imaginary Southern vista to bear upon Hemingway's expatriate narrative provides a unique look into what Paul Giles terms "a transatlantic imaginary," which involves "the interiorization of a literal or metaphorical Atlantic world in all of its expansive dimensions" (1).

In a sense, Hemingway riffs on the power play at work in "Aggravatin" Papa." Mandy Brymm and Brett thus function as analogous threats to male hegemony. ${ }^{6}$ Just as Turk and Robinson displace the sexuality

\footnotetext{
${ }^{6}$ My recognition of this similarity between Brett and Mandy is certainly not intended to level the immense differences between their socioeconomic and cultural conditions. Sandoval offers perhaps the most instructive manner in which to read their distinct yet mutually anti-patriarchal positions: as "two different understandings of domination, subordination and the nature of effective resistance" (75). This allows us to maintain a valuable relation between the two characters and continue to emphasize the oppositional potential they embody. Furthermore, using Sandoval to articulate the nature of their resistance reveals
} 
and anti-patriarchal voice of Mandy to an imagined, racially marked South, so too does the novel attempt to isolate and contain Brett's racially transgressive sexuality at the same time that it produces it. As Lori Robison suggests, "the American cultural investment in region, specifically in the South, can serve larger ideological projects" (67). Deployed subtextually, the space of the South confers an evident political dimension to the novel. The appropriation and suppression of the song thus allows us to interrogate a whole a pattern of narrative relationships that hinge upon the drummer's silenced voice.

\section{III.}

The Zelli's scene in The Sun Also Rises provides a unique opportunity to reconsider the theory of omission as an aesthetic performance of social conflict. What we see in Hemingway's stylistic experimentation is a struggle within the act of mediation, a struggle that evinces the capacity of language to exert-and not merely reflect-an active social force. Thus, readings that rely upon censorship as the final explanation for the drummer's silenced voice remain insufficient. Though such readings attempt to provide a historical public context for this strategy in the text, they also, in the words of Steve Giles, "render virtually impossible the task of clarifying the complex and contradictory set of relationships between (artistic) modernism and

the extent to which these modernist figures perform some of the conflicts within feminist thought, in advance of contemporary theory. 
(societal) modernity" (175). Indeed, the relationship between Brett and the drummer can be seen as "a positive demonstration of modernity" (Stovall, "Gender" 26) on both of their parts; yet the text's attempts to defuse the potentially revolutionary nature of the act signals a moment of ideological crisis.

Despite the fact that elements of the narrative reflect certain social attitudes, it would miss the mark to suggest that the novel sets up a direct confrontation with structures of power. Keneth Kinnamon approximates the veiled presence of all things political in Hemingway's early work: "In his imaginative writing of this first major period of his career, political issues appear more often than has generally been noticed or acknowledged, though they seldom become a major theme" (151). Somewhat problematically, Kinnamon suggests that "major themes" serve as the primary feature by which a text conveys ideological conflict. For Hemingway and his high modernist peers, style was the central concern and driving force of aesthetic innovation, and therefore style provides us with the best tool for investigating the ideological underpinnings of a text. DeKoven emphasizes the profound impact of modernist craft as a political force when she argues that "[t]he debate over the politics of modernist form, like modernist form itself, inhabits and perhaps defines the space of unresolved contradiction or unsynthesized dialectic which... makes modernist form exemplary of the best hope for aesthetic politics in our time" (679). The highly stylized silences that inhabit Hemingway's texts thus provide far more than some submerged 
"feeling." Imbued with geopolitical significance, these narrative spaces actively participate with and intervene in the discursive constructs of modernist cultural production. 0

\section{Works Cited}

Bhabha, Homi K. The Location of Culture. New York: Routledge, 1994. Print.

Comley, Nancy R. and Robert Scholes. Hemingway's Genders:

Rereading the Hemingway Text. New Haven: Yale UP, 1994. Print.

DeKoven, Marianne. "The Politics of Modernist Form." New Literary History 23 (Summer 1992): 675-90. Print.

Duck, Leigh Anne. The Nation's Region: Southern Modernism, Segregation, and U.S. Nationalism. Athens, GA: U of Georgia P, 2006. Print.

Foucault, Michel. The History of Sexuality, Volume I: An Introduction. Trans. Robert Hurley. New York: Pantheon Books, 1978. Print.

Giles, Paul. Virtual Americas: Transnational Fictions and the Transatlantic Imaginary. Durham: Duke UP, 2002. Print.

Giles, Steve. "Afterward: Avant-Garde, Modernism, Modernity: A Theoretical Overview." Theorizing Modernism: Essays in Critical Theory. Ed. Steve Giles. New York: Routledge, 1993. 171-86. Print. 
Hemingway, Ernest. Death in the Afternoon. 1932. New York: Charles Scribner's Sons, 1960. Print.

---. The Sun Also Rises. 1926. New York: Scribner, 2003. Print.

Herring, Scott. "Regional Modernism: A Reintroduction." Modern Fiction Studies 55.1 (Spring 2009): 1-10. Print.

Hunter, Alberta, perf. "Aggravatin' Papa (Don't You Try To Two-Time Me)." By Roy Turk and J. Russel Robinson. Alberta Hunter, Complete Recorded Works in Chronological Order, 1923-1924, Volume 2. Document Records, 1996. CD.

Jameson, Frederic. The Political Unconscious: Narrative as a Socially Symbolic Act. Ithaca, NY: Cornell UP, 1981. Print.

Kennedy, J. Gerald. Imagining Paris: Exile, Writing, and American Identity. New Haven: Yale UP, 1993. Print.

Kinnamon, Keneth. "Hemingway and Politics." The Cambridge Companion to Hemingway. Ed. Scott Donaldson. Cambridge: Cambridge UP, 1996. 149-69. Print.

Moddelmog, Debra A. "Reconstructing Hemingway's Identity: Sexual Politics, the Author, and the Multicultural Classroom." Narrative (October 1993): 187-206. Rpt. in Hemingway: Seven Decades of Criticism. Ed. Linda Wagner-Martin. East Lansing: Michigan State UP, 1998. 239-63. Print. 
Nagel, James. "Literary Impressionism and In Our Time." The Hemingway Review 6.2 (Spring 1987): 17-26. Print.

North, Michael. The Dialect of Modernism: Race, Language, and Twentieth-Century Literature. New York: Oxford UP, 1994. Print.

Peretti, Burton W. "Plantation Cafés: Jazz, Postcolonial Theory, and Modernism." Postcolonial Discourse and Changing Cultural Contexts: Theory and Criticism. Eds. Gita Rajan and Radhika Mohanram. Westport, CT: Greenwood Press, 1995. 89-99. Print.

Robison, Lori. "Region and Race: National Identity and the Southern Past." A Companion to the Regional Literatures of America. Ed. Charles L. Crow. Malden, MA: Blackwell Publishing, 2003. 57-73. Print.

Said, Edward. Culture and Imperialism. New York: Vintage Books, 1994. Print.

Sandoval, Chela. "U.S. Third-World Feminism: The Theory and Method of Oppositional Consciousness in the Postmodern World." Genders 10 (Spring 1991): 1-24. Rpt. in Feminist Postcolonial Theory: A Reader. Eds. Reina Lewis and Sara Mills. New York: Routledge, 2003. 75-99. Print.

Stovall, Tyler. "Gender, Race, and Miscegenation: African Americans in Jazz Age Paris." The Modern Woman Revisited: Paris Between the Wars. Eds. Whitney Chadwick and Tirza True Latimer. New Brunswick, NJ: Rutgers UP, 2003. Print. 
"Aggravatin' Papa"

Pivot 3.1

---. Paris Noir: African Americans in the City of Light. Boston: Houghton Mifflin Company, 1996. Print.

Svoboda, Frederic. "Who Was That Black Man?: A Note on Eugene Bullard and The Sun Also Rises." The Hemingway Review 17.2 (Spring 1998): 105-110. Print.

Turk, Roy and J. Russel Robinson. Aggravatin' Papa (Don't You Try To Two-Time Me). New York: Waterson, Berlin \& Snyder Co., 1922. Print.

Author biography (LINK) Return to contents (LINK) 